\section{Hydrological Properties of Cork Container Media}

\author{
E. Carmona ${ }^{1}$, J. Ordovás ${ }^{2}$, M.T. Moreno ${ }^{2}$, and M. Avilés ${ }^{2}$ \\ Departamento de Ciencias Agroforestales, Universidad de Sevilla, EUITA, \\ Ctra. Utrera, km. 1, 41013 Seville, Spain
}

\section{M.T. Aguado ${ }^{3}$ and M.C. Ortega ${ }^{3}$ \\ Escuela Universitaria de Ingenieros Técnicos Agrícolas. Cortijo de Cuarto, Apartado 11043. 41014 Seville, Spain}

Additional index words. horticultural substrate, growing media, physical properties, hydraulic conductivity, water release curves

\begin{abstract}
Static hydrological properties [aeration capacity, easily available water, reserve water, water release curves: $\theta_{\mathrm{v}}\left(\Psi_{\mathrm{m}}\right)$, and specific humidity curves] and dynamic hydrological properties (saturated and unsaturated hydraulic conductivity) of substrates based on industrial cork residue (the bark of Quercus suber L.) and cork compost were studied. Samples of similar granulometry have been used to establish the effect of cork composting on the aforementioned physical properties. Different models were tested to describe the mechanism of water release from these materials. Van Genuchten's model (Van Genuchten, 1978) was the best fit and produced specific humidity curves that revealed slight differences in the ratio of water capacity function. When cork residues were composted for $\mathbf{7}$ months, important changes occurred in hydrological properties of the material as it became more wettable. Water retention significantly increased from $45 \%$ to $54 \%$, at a potential of $5 \mathrm{kPa}$, although this did not necessarily result in increased water available to plants. A study of the unsaturated hydraulic conductivity ( $\left.K_{\text {unsat }}\right)$ of these materials revealed a significant decrease in the $K_{\text {unst }}$ water potential at $0-5 \mathrm{kPa}$, which corresponds to the range in which the irrigation with these substrates was usually carried out. The long composting process resulted in increased $K_{\text {unsat }}$ between 4 and 5 times that of uncomposted material, which would improve the water supply to the plant.
\end{abstract}

The hydrological characterization of a substrate for container production involves the study of the static properties of the water in the medium (capacity-intensity relations and energetic state of the water in the medium) (Clute, 1986) and of the dynamic parameters, which describe hydraulic conductivity (Fonteno, 1993; Marfa, 1997).

The diversity of materials used as growing media has highly variable water release behaviors (Fonteno et al., 1981; Martinez et al., 1991; Milks et al., 1989a, 1989b, 1989c; Orozco and Marfa, 1995; Riviera et al., 1990). Models to describe water release curves have been developed which relate the volumetric humidity $\left(\theta_{\mathrm{v}} \%\right)$ with matric potentials $\left(\Psi_{\mathrm{m}}\right)$ (Karlovich and Fonteno, 1986; Martínez et al., 1993; Michiels et al., 1993). Water-air relationships can be predicted with these models and the water retention of the substrate determined. For mineral soils, one of the most accepted is Van Genuchten's nonlinear parametric model $(1978,1980)$, which is often used to describe water release in different substrates (Burés et

Received for publication 25 Feb. 2002. Accepted for publication 31 Dec. 2002. This work was financed by the CICYT as part of the AGF94-0941 Project.

${ }^{1}$ Professor. Departamento de Ciencias Agroforestales, Universidad de Sevilla. To whom reprin requests should be addressed; e-mail address: eusebio@us.es

${ }^{2}$ Professor. Departamento de Ciencias Agroforestales, Universidad de Sevilla.

${ }^{3}$ Professor. Escuela Universitaria de Ingenieros Técnicos Agrícolas. Cortijo de Cuarto. Sevilla.

HorTSCIENCE, Vol. 38(6),October 2003 agement of substrate irrigation. In addition to the static conditions of the water in the medium, dynamic parameters must also be considered that permit flows to be estimated.

When substrate $\mathrm{K}_{\text {unsat }}$ is determined in a laboratory it is difficult to generate constant, low rates of water flow that correspond to potentials lower than $-3 \mathrm{kPa}$ (Marfà, 1997). Therefore, in the last few years, models to estimate $\mathrm{K}_{\text {unsat }}$ have been developed from water release curves characteristic for a medium and its saturated conductivity $\left(\mathrm{K}_{\mathrm{sat}}\right)$. The most frequently used model is one developed for field soils by Mualen (1976), which applies the analytical solution proposed by Van Genuchten (1980) and which has also been used in several works to estimate conduction properties in container media (Burés et al., 1997; da Silva, 1991; Orozco, 1995; Orozco and Marfà, 1995; Otten, 1994; Wallach et al., 1992a, 1992b). Experiments have been carried out validating this model, demonstrating that the results accurately coincide with values of $\mathrm{K}_{\text {unsat }}$ obtained experimentally in the laboratory for a wide range of substrates (Burés et al., 1997; Otten, 1994; Wallach et al., 1992b).

The aim of this work is to study both the static and dynamic hydrological properties of industrial cork residue (IC), bark of Quercus suber, and cork compost for use as a container medium. A second objective is to establish the effect of prolonged composting on these properties.

\section{Materials and Methods}

al., 1997; Milks et al., 1989a; Orozco, 1995; Orozco and Marfà, 1995; Otten, 1994; Wallach et al., 1992a, 1992b). This model can be used to determine the water capacity function $\left(\mathrm{d} \theta_{\mathrm{v}} / \mathrm{d} \Psi_{\mathrm{m}}\right)$ in a porous medium (Hillel, 1971). This parameter can be used to compare materials, since it indicates the range of tensions at which the maximum water release ratio occurs and its magnitude.

Water flowing to the roots through a porous medium not only depends on the gradient of the matric potential $\left(\Delta \Psi_{\mathrm{m}} / \Delta \mathrm{x}\right)$, but also on the hydraulic conductivity of the medium. Characteristics of the substrates in a porous matrix determine that slight changes in $\Psi_{\mathrm{m}}$, generally above $-5 \mathrm{kPa}$, are associated with much greater reductions in unsaturated hydraulic conductivity $\left(\mathrm{K}_{\text {unsat }}\right)$ than in field soils $\left(\mathrm{K}_{\text {unsa }}\right.$ in substrates ranged from $10^{-4}$ to $10^{-6} \mathrm{~cm} \cdot \mathrm{min}^{-1}$ ) (da Silva, 1991, 1993; Orozco, 1995; Orozco and Marfà, 1995; Wallach et al., 1992b). It is, therefore, likely that the hydraulic discontinuity imposed by the walls of the container, associated with the sharp drop in $\mathrm{K}_{\text {unsat }}$, produces notable increases in resistance in the soil-root interphase (Nobel, 1994; Passioura, 1988). As a consequence, water stress can be induced in the plant, which affects productive and ecophysiological parameters (Orländer and Due, 1985; Raviv et al., 1993). Significant relationships between growth parameters and substrate $K_{\text {unsat }}$ have been found in lettuce (Marfà et al., 1993), pepper, and carnation (Marfà, 1997). According to Orozco and Marfà (1995), $\Psi_{\mathrm{m}}$ may not be sufficient as the sole parameter in the man-
IC and IC composted for 4 (CC-4) and 7 months (CC-7), all of them with the same particle size distribution, were studied to establish the effects of the composting process on the hydrological characteristics of this material. The granulometry was done on the basis of size distribution standards for IC. These were expressed in relation to volume: $31 \%<0.5 \mathrm{~mm}$; $0.5 \mathrm{~mm}<21 \%<1 \mathrm{~mm} ; 48 \%>1 \mathrm{~mm}$ (Carmona, 1999). Samples were obtained by cutting cylindrical containers, made of eight superposed steel rings $2 \mathrm{~cm}$ high and $8 \mathrm{~cm}$ in diameter, specifically designed for the determination of certain physical parameters in container conditions. The containers were carefully filled, two rings at a time, with the corresponding volume and standard granulometry indicated above, the base of the lower ring being covered with nylon mesh.

Previous trials indicated the difficulty of obtaining perfect saturation of samples in containers by immersion in water for $24-48$ h. For this reason, two saturation methods were used: 1) saturation by immersion for 1 week; and 2) saturation by boiling, which helps to expel the air trapped in pores. With each of the three substrates, a total of 10 containers were filled. Saturation by immersion was carried out in five containers and saturation by boiling in another five. After saturation, the containers were covered by a petri dish to prevent evaporation and drained for $24 \mathrm{~h}$. After this, aluminium plates $0.25 \mathrm{~mm}$ thick were inserted between rings to separate layers. Substrate from the upper ring of each container was not analyzed, 
due to substrate disturbance during handling operations. Nylon mesh attached by elastic bands covered the base of the ring.

Water release curves were determined at low suction $(<1 \mathrm{kPa})$ by a sand bed and at high potential $(1-30 \mathrm{kPa})$ by suction funnels with a porous plate (De Boodt et al., 1974a). Suction values for potentials between 0 and 1 $\mathrm{kPa}$ corresponded to the center of the ring, 2 $\mathrm{cm}$ high. For humidity content at atmospheric pressure, the corresponding value of effective porosity (EP) was taken.

The number of repeats for each material and saturation method were: six for potentials $<1 \mathrm{kPa}$ and from 10 to $30 \mathrm{kPa}$, and 12 for potentials from 1 to $10 \mathrm{kPa}$.

After obtaining the water release curves, the rings filled with substrate were recovered and the pseudoreal density (SPD) was determined by submersion (Ordovás et al., 1996), and also the bulk density (BD) (De Boodt et al., 1974a) in order to calculate the EP of each material.

The empirical data of each set of values $\theta_{\mathrm{v}}\left(\Psi_{\mathrm{m}}\right)$, were used to obtain a mathematical fit of the water release curves. This was done using the following three models:

\section{Martínez et al. (1993):}

$\theta_{\mathrm{v}}=\mathrm{a}+\mathrm{b} \Psi_{\mathrm{m}}+\mathrm{c}\left(\Psi_{\mathrm{m}}\right)^{2}+\mathrm{d}\left(\Psi_{\mathrm{m}}\right)^{3}$

where:

$\theta_{\mathrm{v}}=$ the volumetric water content $(\%)$

$\Psi_{\mathrm{m}}=$ the matric potential or suction $(\mathrm{kPa})$

$\mathrm{a}, \mathrm{b}, \mathrm{c}$, and $\mathrm{d}=$ adjustment coefficients of the regression function

\section{Karlovich and Fonteno (1986):}

$\theta_{\mathrm{v}}=\mathrm{a}+\mathrm{b}\left(\ln \Psi_{\mathrm{m}}\right)+\mathrm{c}\left(\ln \Psi_{\mathrm{m}}\right)^{2}+\mathrm{d}\left(\ln \Psi_{\mathrm{m}}\right)^{3}[2$ where:

$\Psi_{\mathrm{m}}$ and $\theta_{\mathrm{v}}$ correspond to the same parameters with the same units as in the previous model. Likewise, a, b, c, and $\mathrm{d}$ are the corresponding adjustment coefficients.

Table 1. Values of bulk density (BD), pseudoreal density (SPD), and effective porosity (EP) for cork-based substrates.

\begin{tabular}{lccc}
\hline Substrate & $\begin{array}{c}\mathrm{BD} \\
\left(\mathrm{g} \cdot \mathrm{cm}^{-3}\right)\end{array}$ & $\begin{array}{c}\text { SPD } \\
\left(\mathrm{g} \cdot \mathrm{cm}^{-3}\right)\end{array}$ & $\begin{array}{c}\text { EP } \\
(\% \mathrm{vol})\end{array}$ \\
\hline IC & $0.238 \mathrm{a}^{\mathrm{y}}$ & $1.253 \mathrm{a}$ & 81.0 \\
IC-H & $0.236 \mathrm{a}$ & $1.253 \mathrm{a}$ & 81.1 \\
$\mathrm{CC}-4$ & $0.247 \mathrm{a}$ & $1.448 \mathrm{bc}$ & 83.0 \\
CC-4H & $0.238 \mathrm{a}$ & $1.405 \mathrm{~b}$ & 83.1 \\
CC-7 & $0.259 \mathrm{~b}$ & $1.486 \mathrm{c}$ & 82.6 \\
CC-7H & $0.258 \mathrm{~b}$ & $1.483 \mathrm{c}$ & 82.6 \\
\hline
\end{tabular}

${ }^{\mathrm{I}} \mathrm{IC}$ : industrial cork residue saturated by immersion; IC-H: industrial cork residue saturated by boiling; CC-4: cork composted for 4 months and saturated by immersion; CC-4H: cork composted for 4 months and saturated by boiling; CC-7: cork composted for 7 months and saturated by immersion; $\mathrm{CC}-7 \mathrm{H}$ : cork composted for 7 months and saturated by boiling. (n $=35$ for bulk density; $\mathrm{n}=12$ for pseudoreal density in IC, IC-H, and CC-7; $\mathrm{n}=6$ for pseudoreal density in $\mathrm{CC}-4, \mathrm{CC}-4 \mathrm{H}$, and $\mathrm{CC}-7 \mathrm{H}$.)

${ }^{y}$ Any two means within a column not followed by the same letter are significantly different at $P \leq 0.05$, by Tukey's test.

\section{Van Genuchten (1978 and 1980):}

$\theta_{\mathrm{v}}=\theta_{\mathrm{r}}+\left\{\left(\theta_{\mathrm{s}}-\theta_{\mathrm{r}}\right) /\left[\left(1+\left(\alpha \Psi_{\mathrm{m}}\right)^{\mathrm{n}}\right]^{\mathrm{m}}\right\}\right.$

where:

$\theta_{\mathrm{v}}=$ volumetric water content $(\%)$

$\theta_{\mathrm{r}}=$ volumetric residual water content $(\%)$, ( $\theta$ when $\mathrm{d} \theta / \mathrm{d} \Psi_{\mathrm{m}}=0$, excluding the initial plateau of the curve)

$\theta_{\mathrm{s}}=$ volumetric water content at saturation $(\%),\left(\theta_{\mathrm{s}}=\mathrm{EP}\right)$

$\Psi_{\mathrm{m}}=$ matric potential or suction $(\mathrm{kPa})$

$\alpha, \mathrm{n}$, and $\mathrm{m}=$ parameters that define the form of the water release curve

$\theta_{\mathrm{r}}, \alpha$, and $\mathrm{n}$ are determined by fitting the curve. As proposed by Van Genuchten and Nielsen (1985), m can be assumed to be a function of $n: m=1-1 / n$.

After the empirical values for each material $\theta_{\mathrm{v}}\left(\Psi_{\mathrm{m}}\right)$ had been adjusted to fit the Van Genuchten's model, the differential or specific curves of water release $d \theta_{v} / d \Psi_{m}$ were determined (Hillel, 1971).

Determination of $\mathrm{K}_{\text {sat }}$ was carried out with a constant charge permeameter as described by Wallach et al. (1992a). To do this, PVC tubes 20 $\mathrm{cm}$ long and $8 \mathrm{~cm}$ in diameter were filled with substrates of known granulometry. These tubes were filled in five consecutive operations in an attempt to achieve a uniform granulometric distribution throughout the whole tube. After covering the bases with nylon mesh attached by elastic bands, the tubes were placed vertically for saturation for various lengths of time that had been established in previous trials. This varied from 2 weeks in the composted materials (CC-4 and CC-7) to 1 month in the noncomposted residue (IC). After a first determination of $\mathrm{K}_{\text {sat }}$ with this saturation procedure, tubes containing the same sample were submitted to a second saturation by boiling in water for several hours, after which $\mathrm{K}_{\mathrm{sat}}$ was measured again.

Measurements were made within the range of validity of Darcy's law, demonstrating a linear relationship between the pressure gradient applied $(\Delta \mathrm{h})$ and the flow generated $(\mathrm{Q})$. The high $\mathrm{K}_{\mathrm{sat}}$ of cork-based materials makes small $\Delta \mathrm{h}$ values very difficult to measure accurately

Table 2. Volumetric water content $\left(\theta_{v}\right)$ of cork-based substrates ${ }^{z}$ of known granulometry at different suctions.

\begin{tabular}{|c|c|c|c|c|c|c|c|c|c|c|c|c|}
\hline \multirow{2}{*}{$\begin{array}{l}\text { Suction } \\
(\mathrm{kPa})\end{array}$} & \multicolumn{2}{|c|}{$\begin{array}{c}\mathrm{IC} \\
\theta_{\mathrm{v}} \\
\end{array}$} & \multicolumn{2}{|c|}{$\begin{array}{c}\mathrm{IC}-\mathrm{H} \\
\theta_{\mathrm{v}} \\
\end{array}$} & \multicolumn{2}{|c|}{$\begin{array}{c}\mathrm{CC}-4 \\
\theta_{\mathrm{v}} \\
\end{array}$} & \multicolumn{2}{|c|}{$\begin{array}{c}\mathrm{CC}-4 \mathrm{H} \\
\theta_{\mathrm{v}} \\
\end{array}$} & \multicolumn{2}{|c|}{$\begin{array}{c}\mathrm{CC}-7 \\
\theta_{\mathrm{v}} \\
\end{array}$} & \multicolumn{2}{|c|}{$\begin{array}{c}\mathrm{CC}-7 \mathrm{H} \\
\theta_{\mathrm{v}}\end{array}$} \\
\hline & $(\%)$ & $\overline{ \pm \mathrm{SE}}$ & $(\%)$ & $\overline{ \pm \mathrm{SE}}$ & $(\%)$ & $\overline{ \pm \mathrm{SE}}$ & $(\%)$ & $\overline{ \pm \mathrm{SE}}$ & $(\%)$ & $\overline{ \pm \mathrm{SE}}$ & $(\%)$ & $\pm \mathrm{SE}$ \\
\hline 0 & 81.0 & --- & 81.1 & --- & 83.0 & --- & 83.1 & --- & 82.6 & --- & 82.6 & --- \\
\hline 0.1 & 79.2 & 1.49 & 81.1 & --- & 82.3 & 0.74 & 83.1 & --- & 82.6 & --- & 82.6 & --- \\
\hline 0.3 & 77.1 & 1.16 & 81.1 & -- & 79.4 & 0.91 & 83.1 & --- & 82.6 & --- & 82.6 & --- \\
\hline 0.5 & 74.0 & 0.83 & 81.1 & --- & 71.6 & 1.6 & 83.1 & --- & 80.6 & 1.87 & 82.6 & --- \\
\hline 0.7 & 68.3 & 0.46 & 77.1 & 1.10 & 66.5 & 0.98 & 79.6 & 0.97 & 75.2 & 1.65 & 82.4 & 1.51 \\
\hline 0.9 & 64.5 & 0.56 & 73.0 & 1.15 & 62.8 & 0.93 & 74.3 & 0.95 & 73.0 & 1.54 & 78.6 & 1.53 \\
\hline 1.1 & 57.8 & 0.92 & 68.2 & 1.20 & 57.3 & 0.82 & 71.7 & 0.89 & 69.5 & 1.5 & 75.4 & 1.50 \\
\hline 2 & 49.4 & 1.27 & 59.5 & 1.06 & 48.1 & 0.62 & 65.6 & 0.91 & 60.6 & 1.42 & 68.1 & 1.67 \\
\hline 3 & 47.3 & 1.43 & 56.1 & 1.11 & 44.9 & 0.64 & 64.0 & 0.92 & 57.5 & 1.43 & 65.7 & 1.75 \\
\hline 5 & 45.5 & 1.56 & 52.4 & 1.25 & 43.0 & 0.68 & 62.8 & 0.96 & 54.2 & 1.46 & 64.3 & 1.78 \\
\hline 10 & 43.9 & 1.62 & 50.3 & 1.40 & 41.3 & 0.74 & 60.7 & 1.00 & 51.9 & 1.46 & 62.9 & 1.79 \\
\hline 20 & 37.9 & 1.65 & 45.9 & 1.94 & 38.6 & 1.41 & 58.7 & 1.60 & 49.2 & 2.47 & 61.2 & 2.86 \\
\hline 30 & 36.6 & 2.05 & 44.9 & 1.99 & 37.7 & 1.45 & 57.4 & 1.60 & 48.0 & 2.38 & 59.8 & 2.75 \\
\hline
\end{tabular}

${ }^{2} \mathrm{IC}$ : industrial cork residue saturated by immersion; IC-H: industrial cork residue saturated by boiling; CC-4: cork composted for 4 months and saturated by immersion; CC-4H: cork composted for 4 months and saturated by boiling; CC-7: cork composted for 7 months and saturated by immersion; CC-7H: cork composted for 7 months and saturated by boiling. ( $\mathrm{n}=6$ from 0 to 1 and 10 to $30 \mathrm{kPa} ; \mathrm{n}=12$ from 1 to $10 \mathrm{kPa}$. since the $\mathrm{Q}$ produced are so high that they hinder the laminar regime. To eliminate this drawback, $\Delta \mathrm{h}$ was measured with an oil manometer. Six repeat measurements were made for each material saturated by immersion and another six measurements for the material aturated by boiling.

Unsaturated hydraulic conductivity for each suction value: $\mathrm{K}_{\text {unsat }}(\Psi)$, was estimated according to Burdine (1953):

$\mathrm{K}_{\text {unsat }}(\Psi)=\mathrm{K}_{\mathrm{r}}(\Psi) \cdot \mathrm{K}_{\mathrm{sat}}$

In turn, the relative hydraulic conductivity $\left(\mathrm{K}_{\mathrm{r}}\right)$ was estimated from the water release curves using the predictive model proposed by Mualen (1976) for soils:

$\mathrm{K}_{\mathrm{r}}=\left\{1-(\alpha \Psi)^{\mathrm{n}-1}\left[1\left(\alpha \Psi_{\mathrm{m}}^{\mathrm{n}}\right)^{\mathrm{m}}\right\}^{2}\left[1+\left(\alpha \Psi_{\mathrm{m}}\right)^{\mathrm{n}}\right]^{-\mathrm{m} / 2}\right.$ where $\Psi_{\mathrm{m}}$ is the suction value or matric poential and $\alpha, \mathrm{n}$, and $\mathrm{m}$ are the adjustments

\section{Results and Discussion}

EP in cork samples in which several fractions were mixed in the proportion considered to be standard, ranged from $81 \%$ to $83 \%$ (Table 1). Localization of the finest particles between interparticular pores explained why these values are lower than those reported by to $86 \%$. In our samples, particles smaller than $0.25 \mathrm{~mm}$ represented $15.5 \%$ of the real volume of material and $\approx 3 \%$ of the apparent substrate volume for the IC samples. Their presence, therefore, would reduce EP by $\approx 3 \%$ in the mixture of the fractions.

Composting increased SPD (Table 1). This could be due to alteration and perforation of the cork walls in the cells nearer the surface of the particle, which would then become halfoccluded pores in contact with the exterior. Similarly, Ordovás et al. (1996) observed a slight decrease in the occluded porosity as the composting process progressed. The small increases in EP observed indicate the very minor Genuchten's model $(1978,1980)$. based substrates in which EP ranged from 84 

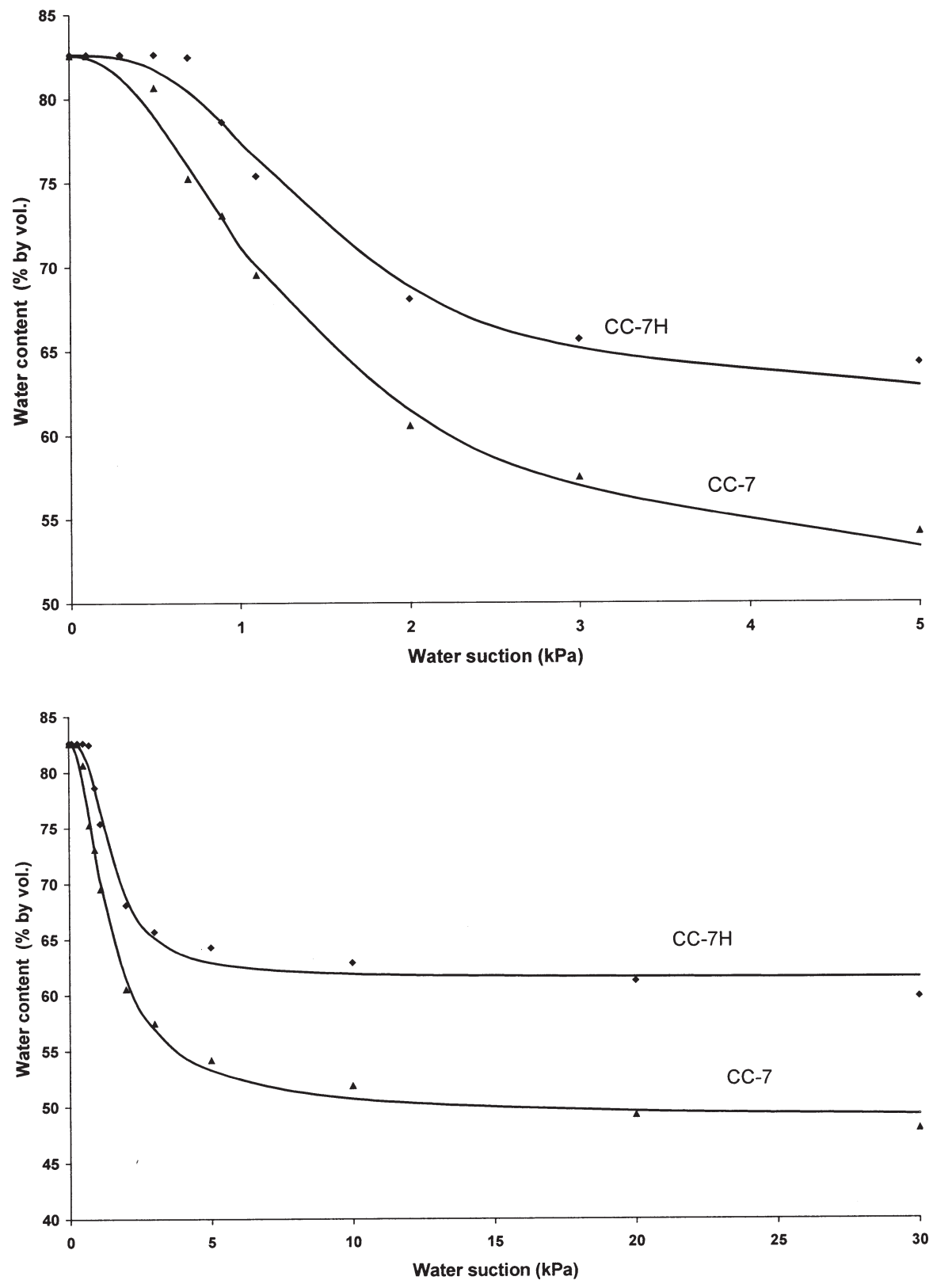

Fig. 1. Comparison of the experimental values of water release curves from cork composted for 7 months saturated by immersion (CC-7) or by boiling (CC-7H), at medium-low (0-5 kPa) and high (0-30 kPa) water suction and the adjustments obtained with Van Genuchten's model (continuous line). physical alteration that this material suffered as a consequence of microbial attack. This agrees with the results obtained by Avilés et al. (1996), who did not record the presence of typically lignolytic fungi (Basydiomycetes) during the whole composting process of cork residues. This demonstrated the high biological stability of this material even in conditions conducive to decomposition.

The water content at $0.1 \mathrm{kPa}$ (Table 2) showed that $48 \mathrm{~h}$ of submersion was sufficient to achieve saturation, which is unusual in substrates. This is likely due to the reduced thickness of the samples (rings $2 \mathrm{~cm}$ high) and to the previous saturation of the container by boiling or prolonged immersion for a week. In any case, with the first saturation of the container, only $75 \%$ to $90 \%$ of EP was achieved (data not shown), which coincides with that described for other materials (Da Silva, 1991; Martínez et al., 1993; Wallach et al., 1992a).

The air entry suctions $\left(\Psi_{\mathrm{e}}\right)$ were higher when the materials were saturated by boiling than by immersion (Table 2). A similar effect appeared to occur with prolonged composting, since $\Psi_{\mathrm{e}}$ increased from $0.1 \mathrm{kPa}$ in fresh material to $0.4 \mathrm{kPa}$ in a 7 -month-old compost. This increase in water retention capacity through boiling or composting was more evident at suctions above 1 or $2 \mathrm{kPa}$, demonstrated by water contents increasing from $40 \%$ to $60 \%$ depending on the materials. The water release curves, adjusted to fit the Van Genuchten's model, graphically showed the effect of boiling on CC-7 (Fig. 1).

This increase could be explained by alterations in the physical structure of the material after the aforementioned treatments, which resulted in a rise in the proportion of micropores (swelling of particles and sealing of pores, disintegration of the larger particles, perforation of cell walls, and appearance of new half-occluded pores, etc.). However, the slight rises in BD, SPD, and EP observed after boiling or composting (Table 1) could not alone explain the magnitude of the increase of water retention.

Boiling or biological degradation during composting reduced the content of substances with a strong hydrophobic character, such as suberin, waxes, and resins, which are com-
Table 3. Aeration capacity (AC), easily available water (EAW), and reserve water (RW) of corkbased substrates of known granulometry.

\begin{tabular}{lccc}
\hline Substrate $^{z}$ & $\begin{array}{c}\text { AC } \\
(\%)\end{array}$ & $\begin{array}{c}\text { EAW } \\
(\%)\end{array}$ & $\begin{array}{c}\text { RW } \\
(\%)\end{array}$ \\
\hline IC & 19.8 & 15.6 & 1.6 \\
IC-H & 10.5 & 18.2 & 2.1 \\
CC-4 & 22.9 & 17.0 & 1.7 \\
CC-4H & 10.1 & 10.2 & 2.1 \\
CC-7 & 11.3 & 17.1 & 2.3 \\
CC-7H & 5.6 & 12.75 & 1.4 \\
Ideal substrate & $20-30$ & $20-30$ & $4-10$ \\
\hline
\end{tabular}

${ }^{\mathrm{z}} \mathrm{IC}$ : Industrial cork residue saturated by immersion; IC-H: Industrial cork residue saturated by boiling; CC-4: cork composted for 4 months and saturated by immersion; CC-4H: cork composted for 4 months and saturated by boiling; CC-7: cork composted for 7 months and saturated by immersion; CC-7H: cork composted for 7 months and saturated by boiling.
Table 4. Values of the coefficients for adjustment of the water release curves to the model by Martínez et al. (1993). ${ }^{2}$

\begin{tabular}{lcrccc}
\hline & \multicolumn{5}{c}{ Regression coefficients } \\
\cline { 2 - 5 } Substrate $^{\mathrm{y}}$ & $\mathrm{a}$ & \multicolumn{1}{c}{$\mathrm{b}$} & $\mathrm{c}$ & $\mathrm{d}$ & $r^{2}$ \\
\hline IC & $84.70^{* *}$ & $-13.34^{\mathrm{NS}}$ & $-11.48^{\mathrm{Ns}}$ & $3.56^{\mathrm{Ns}}$ & 0.90 \\
IC-H & $83.43^{* *}$ & $3.70^{\mathrm{Ns}}$ & $-20.83^{*}$ & $5.12^{*}$ & 0.92 \\
CC-4 & $87.60^{* *}$ & $-17.64^{\mathrm{Ns}}$ & $-11.47^{\mathrm{Ns}}$ & $3.97^{\mathrm{Ns}}$ & 0.90 \\
CC-4H & $85.33^{* *}$ & $-1.19^{\mathrm{Ns}}$ & $-12.43^{\mathrm{Ns}}$ & $3.27^{\mathrm{Ns}}$ & 0.88 \\
CC-7 & $85.10^{* *}$ & $0.04^{\mathrm{Ns}}$ & $-17.91^{*}$ & $4.61^{*}$ & 0.92 \\
CC-7H & $84.09^{* *}$ & $3.94^{\mathrm{Ns}}$ & $-14.77^{*}$ & $3.61^{*}$ & 0.88 \\
\hline
\end{tabular}

${ }^{\mathrm{z}} \theta_{\mathrm{v}}=\mathrm{a}+\mathrm{b} \Psi_{\mathrm{m}}{ }^{1 / 3}+\mathrm{c} \Psi_{\mathrm{m}}{ }^{2 / 3}+\mathrm{d} \Psi_{\mathrm{m}}$; where: $\theta_{\mathrm{v}}$ is the volumetric water content (\%) and $\Psi_{\mathrm{m}}$ is the suction $(\mathrm{kPa})$.

y IC: industrial cork residue saturated by immersion; IC-H: industrial cork residue saturated by boiling; CC-4: cork composted for 4 months and saturated by immersion; $\mathrm{CC}-4 \mathrm{H}$ : cork composted for 4 months and saturated by boiling; CC-7: cork composted for 7 months and saturated by immersion; CC-7H: cork composted for 7 months and saturated by boiling.

Ns, ${ }^{*},{ }^{* *}$ Nonsignificant or significant at $P \leq 0.05$ or 0.01 , respectively, by Student's $t$ test. 
Table 5. Values of the regression coefficient for adjustment of the water release curve to the model by Karlovich and Fonteno (1986) 2 .

\begin{tabular}{lccccc}
\hline & \multicolumn{5}{c}{ Regression coefficients } \\
\cline { 2 - 5 } Substrate $^{\mathrm{y}}$ & $\mathrm{a}$ & $\mathrm{b}$ & $\mathrm{c}$ & $\mathrm{d}$ & $r^{2}$ \\
\hline IC & $62.56^{* *}$ & $-12.24^{* *}$ & $-0.51^{\mathrm{NS}}$ & $0.60^{*}$ & 0.95 \\
IC-H & $71.15^{* *}$ & $-11.63^{* *}$ & $-1.31^{* *}$ & $0.77^{* *}$ & 0.97 \\
$\mathrm{CC}-4$ & $61.02^{* *}$ & $-13.60^{* *}$ & $-0.07^{\text {Ns }}$ & $0.66^{* *}$ & 0.97 \\
$\mathrm{CC}-4 \mathrm{H}$ & $74.62^{* *}$ & $-8.41^{* *}$ & $-0.67^{\mathrm{Ns}}$ & $0.53^{* *}$ & 0.94 \\
$\mathrm{CC}-7$ & $71.36^{* *}$ & $-11.11^{* *}$ & $-0.97^{* *}$ & $0.70^{* *}$ & 0.98 \\
CC-7H & $76.83^{* *}$ & $-7.92^{* *}$ & $-0.98^{*}$ & $0.58^{* *}$ & 0.95 \\
\hline
\end{tabular}

${ }^{\mathrm{z}} \theta_{\mathrm{v}}=\mathrm{a}+\mathrm{b}\left(\ln \Psi_{\mathrm{m}}\right)+\mathrm{c}\left(\ln \Psi_{\mathrm{m}}\right)^{2}+\mathrm{d}\left(\ln \Psi_{\mathrm{m}}\right)^{3}$, where: $\theta_{\mathrm{v}}$ is the volumetric water content $(\%)$ and $\Psi_{\mathrm{m}}$ the suction $(\mathrm{kPa})$.

${ }^{\mathrm{y}} \mathrm{IC}$ : industrial cork residue saturated by immersion; IC-H: industrial cork residue saturated by boiling; CC-4: cork composted for 4 months and saturated by immersion; $\mathrm{CC}-4 \mathrm{H}$ : cork composted for 4 months and saturated by boiling; CC-7: cork composted for 7 months and saturated by immersion; CC-7H: cork composted for 7 months and saturated by boiling.

Ns, *,** Nonsignificant or significant at $P \leq 0.05$ or 0.01 , respectively, by Student's $t$ test.
Table 6. Values of the parameters for the adjustment of water release curves to the model by Van Genuchten (1978). ${ }^{2}$

\begin{tabular}{|c|c|c|c|c|c|}
\hline \multirow[b]{2}{*}{ Substrate ${ }^{y}$} & \multicolumn{4}{|c|}{ Regression coefficients } & \multirow[b]{2}{*}{$r^{2}$} \\
\hline & $\overline{\theta_{\mathrm{r}}(\%)}$ & $\alpha\left(\mathrm{kPa}^{-1}\right)$ & $\mathrm{n}$ & $\mathrm{m}$ & \\
\hline$\overline{\mathrm{IC}}$ & 37.97 & 1.48 & 2.031 & 0.508 & 0.99 \\
\hline IC-H & 46.10 & 0.89 & 2.294 & 0.564 & 0.99 \\
\hline CC-4 & 38.32 & 1.64 & 2.177 & 0.541 & 0.997 \\
\hline $\mathrm{CC}-4 \mathrm{H}$ & 59.27 & 1.04 & 2.598 & 0.615 & 0.98 \\
\hline CC-7 & 48.73 & 1.03 & 2.215 & 0.549 & 0.99 \\
\hline $\mathrm{CC}-7 \mathrm{H}$ & 61.51 & 0.80 & 2.958 & 0.662 & 0.99 \\
\hline
\end{tabular}

${ }^{\mathrm{z}} \theta_{\mathrm{v}}=\theta_{\mathrm{r}}+\left\{\left(\theta_{\mathrm{s}}-\theta_{\mathrm{r}}\right) /\left[1+\left(\alpha \Psi_{\mathrm{m}}\right)^{\mathrm{n}}\right]^{\mathrm{m}}\right\}$; where: $\theta_{\mathrm{v}}=$ volumetric water content $(\%) ; \theta_{\mathrm{s}}=$ volumetric water content at saturation $(\%) ; \theta_{\mathrm{r}}=$ volumetric residual water content $(\%) ; \Psi_{\mathrm{m}}=$ suction $(\mathrm{kPa})$.

yIC: industrial cork residue saturated by immersion; IC-H: Industrial cork residue saturated by boiling; CC-4: cork composted for 4 months and saturated by immersion; CC-4H: cork composted for 4 months and saturated by boiling; CC-7: cork composted for 7 months and saturated by immersion; CC-7H: cork composted for 7 months and saturated by boiling. mon components of cork cell walls (Carmona, 1999). This could explain the significant rise in water content and wettability of the material after treatment in comparison to the fresh material. The presence of these substances increases the angle of contact between the water and the surface of the cork inducing the pores to empty at a potential lower than that estimated by the law of capillarity for the case of complete wetness (angle of contact $\alpha=0$ ) (Hillel, 1971). It could be concluded, therefore, that an increase in water content after treatment would be more likely, due to a greater affinity of this material for the water rather than a change in its physical properties.

Substrate-water relationship parameters (De Boodt et al., 1974a, 1974b) of the materials studied and their comparison with the substrate considered as "ideal" (Table 3 ) showed that the aeration capacity (AC), the easily available water (EAW), and the reserve water (RW) are slightly below values considered as optimal. Although prolonged composting reduced the aeration capacity well below the optimum, Ordovás et al. (1997) demonstrated that the difficulty in saturating cork-based substrates under real cultivation conditions ensured adequate aeration of the root system even in shallow containers. Although composting of the material produced an important increase in water retention, this did not result in increased water availability to the plant.

Equations [1] and [2] were not satisfactory to describe the mode of water release from cork and composts of cork-based substrates, in spite of the high determination coefficients obtained in the regressions for the adjustment to empirical values (Tables 4 and 5). Both polynomial functions were good at predicting the water release capacity in the first part of the curve

(right) Fig. 2. Comparison of the experimental values of water release curves, at medium-low $(0-5$ $\mathrm{kPa}$ ) water suction, and the adjustments obtained with Van Genuchten's model (continuous line). IC: industrial cork residue saturated by immersion; IC-H: industrial cork residue saturated by boiling; CC-4: cork composted for 4 months and saturated by immersion; $\mathrm{CC}-4 \mathrm{H}$ : cork composted for 4 months and saturated by boiling.
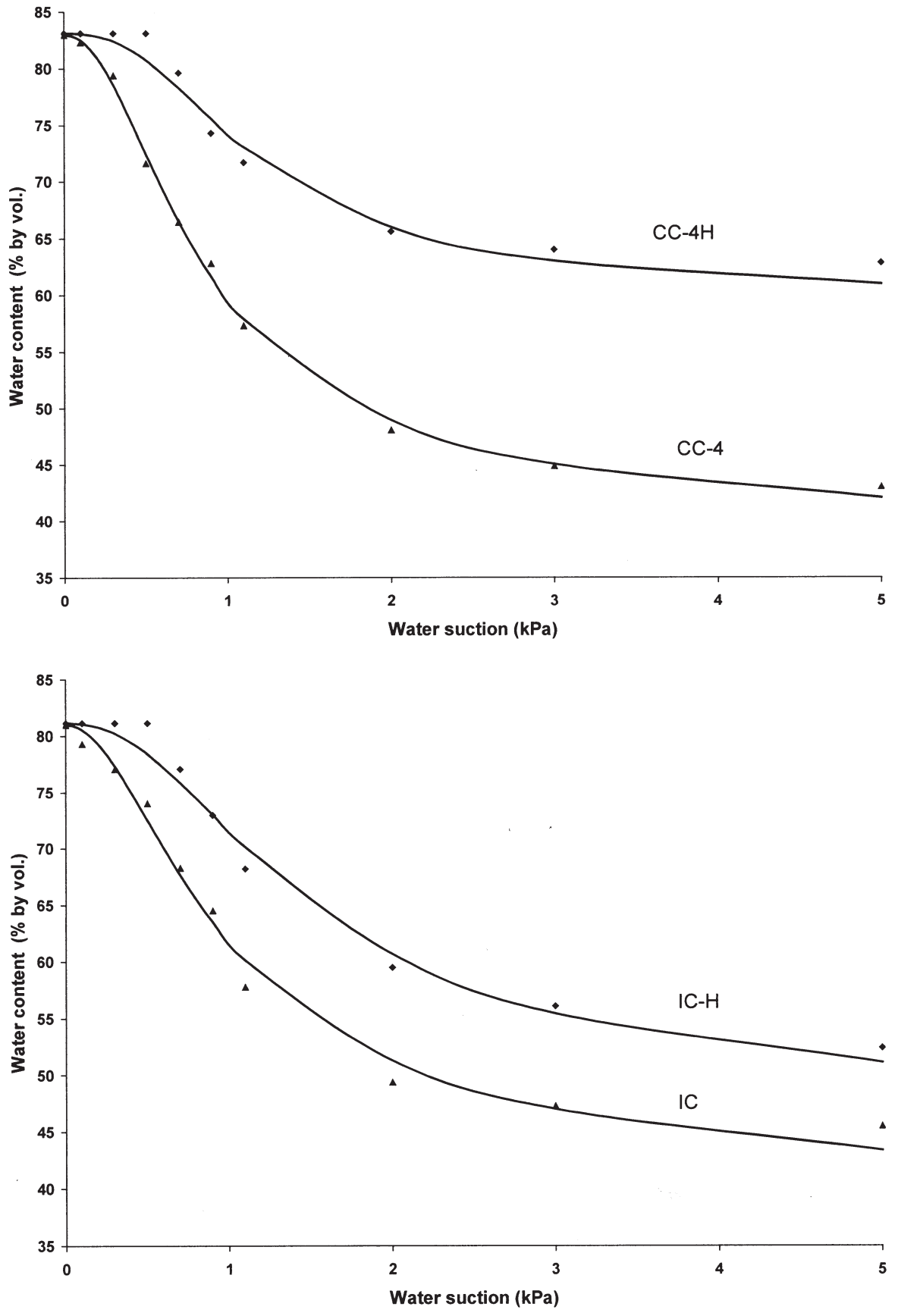
$(1-10 \mathrm{kPa})$, but logically this deviated from the experimental data in sections where $\mathrm{d} \theta_{\mathrm{v}} / \mathrm{d} \Psi_{\mathrm{m}}$ approaches zero. The initial plateau presented by materials with a large $\Psi_{\mathrm{e}}(\mathrm{ICH} ; \mathrm{CC}-4 \mathrm{H}$; CC$7 \mathrm{H}$; and $\mathrm{CC}-7)$, and the residual water content $\left(\theta_{\mathrm{r}}\right)$, corresponding to potentials above 10-20 $\mathrm{kPa}$, therefore, could not be described by these models. In any case, it is worth noting that these models were proposed to predict the mode of water release under conditions of container capacity, i.e., at low suctions where they did seem to give a good fit.

The nonlinear parametric model of Van Genuchten $(1978,1980)$, originally developed for soils (high values of $\Psi_{\mathrm{e}}$ ), gave a good description of the mode of water release in the substrates studied (Table 6). It could correctly predict the initial section of the release curve ( $\Psi_{\mathrm{m}}$ between 0 and $5 \mathrm{kPa}$ ) and $\theta_{\mathrm{v}}$ at high suctions ( $\Psi_{\mathrm{m}}$ between 10 and $30 \mathrm{kPa}$ ) (Figs. 1 and 2).

The water capacity function (Hillel, 1971) obtained from the derivative of the functions corresponding to the fits of the experimental data to the Van Genuchten model (Fig. 3) showed that the boiling process in IC-H and $\mathrm{CC}-4 \mathrm{H}$ brought about a increase in the water suction where the maximum rate of water release occurs $(\approx 0.4-0.9 \mathrm{kPa})$. This process also resulted in a reduction in the rate of water release at low suctions. It could also be observed that the ratio of release was similar above suctions of $1.2 \mathrm{kPa}$ for IC and above $2 \mathrm{kPa}$ for CC- 4 independent of the saturation treatment. The water capacity function of CC-7 (not shown) was similar. Likewise, longer durations of the composting process (CC-7) resulted in a slight increase of the water suction in which maximum release occurs. In any case, above $1.5 \mathrm{kPa}$ the three materials demonstrated the same release rate and it could, therefore, be concluded that composting did not produce a significant improvement in the characteristics of water release.

Saturated hydraulic conductivity $\left(\mathrm{K}_{\text {sat }}\right)$ (Table 7) was similar to those obtained by other authors in different growing media: 0.52 to $7 \mathrm{~cm} \cdot \mathrm{min}^{-1}$ for tuff and composted agricultural residues (Wallach et al., 1992a, $1992 \mathrm{~b}$ ); from 0.3 to $0.8 \mathrm{~cm} \cdot \mathrm{min}^{-1}$ for fine expanded perlites: B6, B9, B10, and B12 (Orozco and Marfà, 1995; Orozco, 1995). According to Otten (1994), an interval of between 0.1 and $6.0 \mathrm{~cm} \cdot \mathrm{min}^{-1}$ has been described as normal for the substrates, although in very large perlites (A13) Orozco and Marfà (1995) measured up to $181 \mathrm{~cm} \cdot \mathrm{min}^{-1}$.

The increase in $\mathrm{K}_{\mathrm{sat}}$ after boiling could be due to better saturation of the substrate, caused by physical and chemical changes such as improved wettability of the material. This latter phenomenon was supported by the fact that a second boiling process considerably increased $\mathrm{K}_{\text {sat }}$ in comparison to the same material only boiled once (data not shown). The increase in $\mathrm{K}_{\text {sat }}$ with composting could be interpreted in a similar way. However, in this case the different packaging of the particles among the samples compared introduced another error factor, as it induces changes in the geometry of the interparticular pores and tortuosity, which affected $\mathrm{K}_{\mathrm{sat}}$. Otherwise, it would be difficult
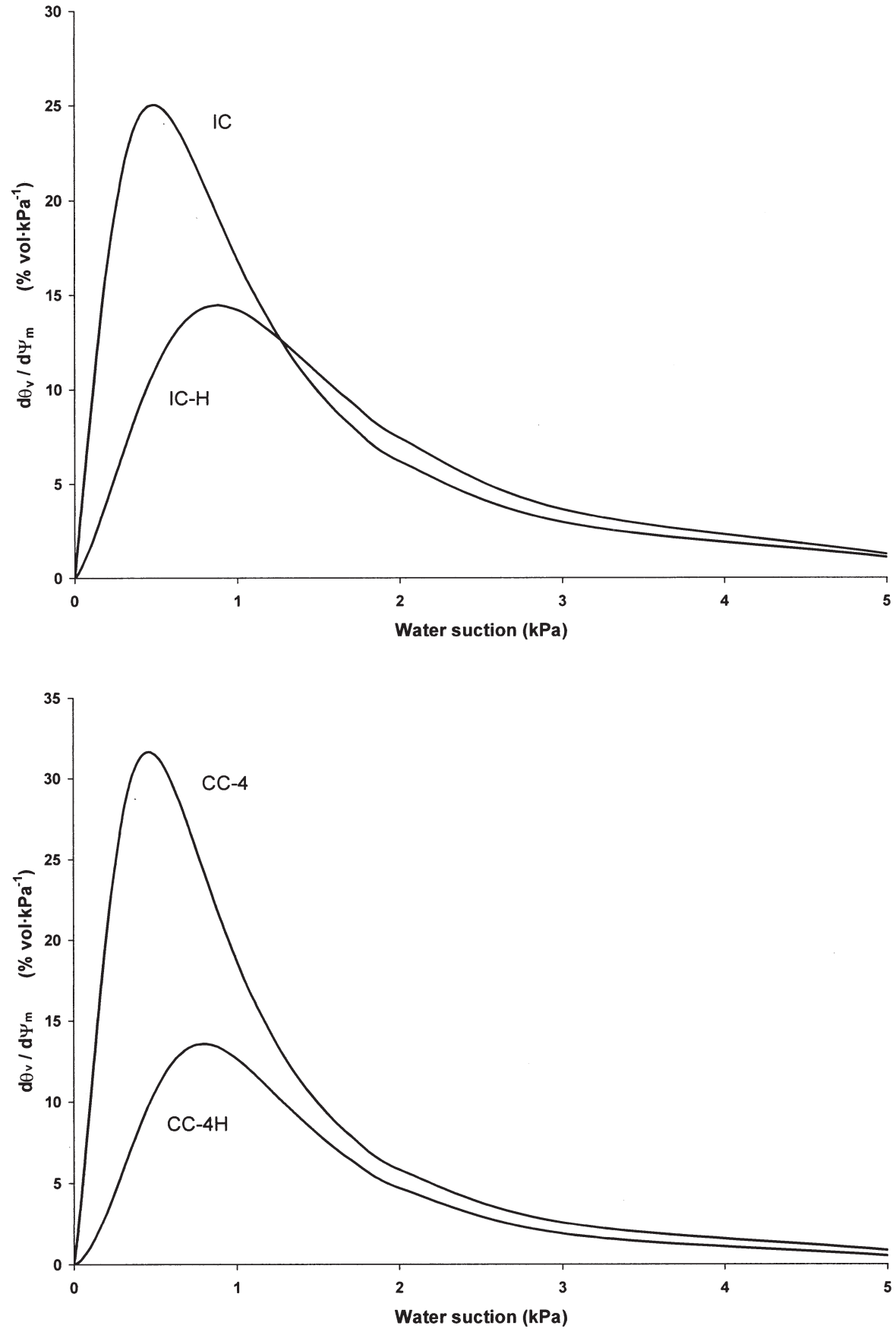

Fig. 3. Specific water release curves $\left(\mathrm{d} \theta_{\mathrm{v}} / \mathrm{d} \Psi_{\mathrm{m}}\right)$. IC: industrial cork residue saturated by immersion; IC-H: industrial cork residue saturated by boiling; $\mathrm{CC}-4$ : cork composted for 4 months and saturated by immersion; CC-4H: cork composted for 4 months and saturated by boiling.

Table 7. Saturated hydraulic conductivity $\left(\mathrm{K}_{\mathrm{s}}\right)$.

\begin{tabular}{lllllll}
\hline Substrate $^{\mathrm{z}}$ & $\mathrm{IC}$ & $\mathrm{IC}-\mathrm{H}$ & $\mathrm{CC}-4$ & $\mathrm{CC}-4 \mathrm{H}$ & $\mathrm{CC}-7$ & $\mathrm{CC}-7 \mathrm{H}$ \\
\hline $\mathrm{K}_{\mathrm{s}}\left(\mathrm{cm} \cdot \mathrm{min}^{-1}\right)$ & 0.72 & 1.67 & 1.64 & 2.98 & 1.04 & 2.70 \\
$\pm \mathrm{SE}$ & 0.051 & 0.307 & 0.343 & 0.383 & 0.078 & 0.124 \\
\hline
\end{tabular}

${ }^{\mathrm{z}} \mathrm{IC}$ : industrial cork residue saturated by immersion; IC-H: industrial cork residue saturated by boiling; CC-4: cork composted for 4 months and saturated by immersion; CC-4H: cork composted for 4 months and saturated by boiling; CC-7: cork composted for 7 months and saturated by immersion; $\mathrm{CC}-7 \mathrm{H}$ : cork composted for 7 months and saturated by boiling. $(n=6$.) 
to explain the greater conduction capacity in CC-4 compared to CC-7.

The $\mathrm{K}_{\text {unsat }}$ estimated from the Mualen model (1976) and the analytical solution of Van Genuchten $(1978,1981)$ (Table 8) showed for all the materials studied a strong reduction in $\mathrm{K}_{\text {unsat }}$ as the humidity was reduced. This drop, to $10^{-6}$ and $10^{-7}$ of the saturation value in the suction interval from 0 to $10 \mathrm{kPa}$, was in the order of 100 to 1000 times larger than that described for soils by Hillel (1971) (up to $10^{-5}$ of the saturation value but in the interval from 0 to $100 \mathrm{kPa}$ ) and its magnitude coincided with values recorded for materials used as growing media (Burés et al., 1997; Orozco, 1995; Orozco and Marfà, 1995; Wallach et al., 1992a, 1992b).

The sharp drop in hydraulic conductivity of the substrates can be explained by the increased presence of large pores. Therefore, at weaker suctions these emptied very quickly producing a rapid decrease in the conduction section and an increase in tortuosity.

Comparison of the $\mathrm{K}_{\text {unsat }}$ values of the materials studied in the interval of $\Psi_{\mathrm{m}}$ in which irrigation of the substrates usually takes place showed that the materials submitted to prolonged composting presented water transmission capacities between 4 and 5 times greater than noncomposted materials. Therefore, at the same evapotranspiration demand, plants cultivated in these materials would have different rates of water supplied in spite of the same matric potential of the cultivation medium. These differences would be expected to bring about different transpiratory behaviors that would oblige the plant to adopt strategies to maintain the equilibrium between transpiration and absorption. These might include increasing the area of root absorption, osmotic adjustment, reducing foliate expansion, closure of stomas, etc., which would correspond to less growth of the aerial part, and reduced production and commercial value of the plant.

The composting process of cork residues produced only a slight alteration in the porous structure of the particles. The increase in the water retention capacity observed after boiling or composting the residues studied was mainly due to a greater affinity of the material for water resulting from the degradation of hydrophobic substances during these processes. In any case, the increase reported in this parameter did not cause an increase in easily available water to the plant. Composting appeared to increase the water conduction capacity in subsaturation conditions, which would improve the rate of water supply to plants.

\section{Literature Cited}

Avilés, M., E. Carmona, J. Ordovás, and M.C. Ortega. 1996. Evolución de la carga fúngica durante el compostaje del residuo industrial del corcho para su uso como sustrato de cultivo hortícola y silvícola. Invest Agr.: Prod. Prot. Veg. 11:301-311.

Burdine, N.T. 1953. Relative permeability calculations from poro size distribution data. Trans. AIME 198:71-78.

Table 8. Unsaturated hydraulic conductivity $[\mathrm{K}(\Psi)]\left(\mathrm{cm} \cdot \mathrm{h}^{-1}\right)$ estimated from the analytical solution of Van Genuchten (1978 and 1981). ${ }^{2}$

\begin{tabular}{|c|c|c|c|c|c|c|}
\hline \multirow{2}{*}{$\begin{array}{l}\text { Suction } \\
(\mathrm{kPa})\end{array}$} & \multicolumn{6}{|c|}{ Substrate $^{y}$} \\
\hline & CC-7H & CC-7 & CC-4H & CC-4 & IC-H & IC \\
\hline 0 & $1.62 \cdot 10^{2}$ & 62.2 & $1.79 \cdot 10^{2}$ & 98.4 & $1.00 \cdot 10^{2}$ & 43.2 \\
\hline 0.2 & $1.53 \cdot 10^{2}$ & 45.2 & $1.50 \cdot 10^{2}$ & 53.3 & 79.8 & 22.3 \\
\hline 0.3 & $1.42 \cdot 10^{2}$ & 36.1 & $1.27 \cdot 10^{2}$ & 34.9 & 67.3 & 15.1 \\
\hline 0.4 & $1.28 \cdot 10^{2}$ & 28.0 & $1.02 \cdot 10^{2}$ & 22.0 & 55.2 & 9.96 \\
\hline 0.6 & 95.1 & 15.9 & 59.1 & 8.49 & 34.9 & 4.33 \\
\hline 0.7 & 78.2 & 11.8 & 43.0 & 5.34 & 27.1 & 2.89 \\
\hline 1 & 37.1 & 4.71 & 15.2 & 1.49 & 12.2 & $9.51 \cdot 10^{-1}$ \\
\hline 2 & 1.83 & $3.51 \cdot 10^{-1}$ & $6.41 \cdot 10^{-1}$ & $7.31 \cdot 10^{-2}$ & 1.02 & $6.43 \cdot 10^{-2}$ \\
\hline 3 & $1.52 \cdot 10^{-1}$ & $5.51 \cdot 10^{-2}$ & $6.69 \cdot 10^{-2}$ & $1.07 \cdot 10^{-2}$ & $1.58 \cdot 10^{-1}$ & $1.11 \cdot 10^{-2}$ \\
\hline 4 & $2.27 \cdot 10^{-2}$ & $1.38 \cdot 10^{-2}$ & $1.25 \cdot 10^{-2}$ & $2.64 \cdot 10^{-3}$ & $3.84 \cdot 10^{-2}$ & $3.09 \cdot 10^{-3}$ \\
\hline 5 & $5.03 \cdot 10^{-3}$ & $4.63 \cdot 10^{-3}$ & $3.36 \cdot 10^{-3}$ & $8.86 \cdot 10^{-4}$ & $1.24 \cdot 10^{-2}$ & $1.13 \cdot 10^{-3}$ \\
\hline 10 & $4.35 \cdot 10^{-5}$ & $1.46 \cdot 10^{-4}$ & $5.39 \cdot 10^{-5}$ & $2.92 \cdot 10^{-5}$ & $3.45 \cdot 10^{-4}$ & $4.85 \cdot 10^{-5}$ \\
\hline 20 & $3.68 \cdot 10^{-7}$ & $4.49 \cdot 10^{-6}$ & $8.48 \cdot 10^{-7}$ & $9.53 \cdot 10^{-7}$ & $9.26 \cdot 10^{-6}$ & $2.04 \cdot 10^{-6}$ \\
\hline 30 & $2.25 \cdot 10^{-8}$ & $5.84 \cdot 10^{-7}$ & $7.46 \cdot 10^{-8}$ & $1.29 \cdot 10^{-7}$ & $1.11 \cdot 10^{-6}$ & $3.20 \cdot 10^{-7}$ \\
\hline $\begin{array}{l}{ }^{2} \mathrm{~K}(\Psi)= \\
=\text { suctio } \\
{ }^{y} \mathrm{IC} \text { : Ind } \\
\text { CC-4: c } \\
\text { and satı } \\
\text { compos }\end{array}$ & y boiling; & urated by i & $\begin{array}{l}\left.\left.\alpha \Psi_{\mathrm{m}}\right)^{\mathrm{n}}\right]^{\mathrm{m} / 2} ; \\
\text { he adjustme } \\
\text { ersion; IC-1 } \\
\text { ated by imı }\end{array}$ & $\begin{array}{l}: \mathrm{K}_{\mathrm{s}}=\text { satur } \\
\text { water relea } \\
\text { lustrial cor } \\
\text { on; } \mathrm{CC}-4 \mathrm{H}\end{array}$ & $\begin{array}{l}\text { conductiv } \\
\text { urves to em } \\
\text { sidue satur } \\
\text { k compost }\end{array}$ & $\begin{array}{l}\left(\mathrm{cm} \cdot \mathrm{h}^{-1}\right) ; \Psi_{\mathrm{n}} \\
\text { ical data. } \\
\text { d by boiling } \\
\text { for } 4 \text { months } \\
\text { CC-7H: cork }\end{array}$ \\
\hline
\end{tabular}

Burés, S., O. Marfà, T. Pérez, J.A. Tébar, and A. Lloret. 1997. Measure of substrates unsaturated hydraulic conductivity. Acta Hort. 450:297-303.

Carmona, E. 1999. Estudio del compost de corcho como sustrato hortícola y silvícola. PhD Diss., Univ. Politécnica de Valencia.

Da Silva, F.F. 1991. Static and dynamic characterization of container medias as a basis for irrigation management. MS Thesis, Hebrew Univ. of Jerusalem.

Da Silva, F.F., R. Wallach, and Y. Chen. 1993. Hydraulic properties of sphagnum peat moss and tuff (scoria) and their potential effects on water availability. Plant Soil 154:385-390.

De Boodt, M., O. Verdonck, and I. Cappaert. 1974a. Method for measuring the water release curve of organic substrates: Acta Hort. 37:2054-2062.

De Boodt, M., O. Verdonck, and I. Cappaert. 1974b. Determination and study of the water availability of substrates of ornamental plant growing. Acta Hort. 35:51-58.

Fonteno, W.C. 1993. Problems and considerations in determining physical properties of horticultural substrates. Acta Hort. 342:197-204.

Fonteno, W.C., O.K.Cassel, and R.A. Larson. 1981. Physical properties of three container media and their effect on poinsettia growth. J. Amer. Soc. Hort. Sci., 106:736-741.

Hillel, D. 1971. Soil and water. Physical principles and processes. Academic Press, Orlando, Fla.

Karlovich, P.T. and W.C. Fonteno. 1986. Effect of soil moisture tension and soil water content on the growth of chrysanthemum in 3 container media. J. Amer. Soc. Hort. Sci. 111:191-195.

Klute, A. and C. Dirksen. 1986. Hydraulic conductivity and diffusivity, p. 687-734. In: A. Klute (ed.). Methods of soil analysis. Part. 1. Physical and mineralogical methods. Monogr. 9. Amer. Soc. Agron., Madison, Wis.

Marfà, O. 1997. La gestión del agua en la fertirrigación de sustratos en cultivo sin suelo. Actas Hort. 19:221-239.

Marfà, O., A. Martínez, R. Orozco, L. Serrano, and X. Martínez. 1993. The use of fine-grade perlites in lettuce bag cultures. II Physical properties, rheologic effects and productivity. Acta Hort. 342:339-348.

Martínez, F.X., S. Burés, F. Blanca, M.P. Yuste, and J. Valero. 1991. Experimental and theoretical air/water ratios of different substrate mixtures at container capacity: Acta Hort. 294:241-248.

Martínez, F.X., J. Valero, O. Marfà, and R. Orozco. 1993. Regresión polinómica para el ajuste de las curvas de liberación de agua y predicción del contenido de agua en sacos de perlita. Actas Hort. 10:1143-1151.

Michiels, P., R. Hartmann, and C. Coussens. 1993. Physical properties of peat substrates in an ebb/flood irrigation system. Acta Hort. 342:205-219.

Milks, R.R., W.C. Fonteno, and R.A. Larson. 1989a. Hydrology of horticultural substrates: I. Mathematical models for moisture characteristics of horticultural container media. J. Amer. Soc. Hort. Sci. 114:48-52.

Milks, R.R.,W.C. Fonteno, and R.A.Larson. 1989b. Hydrology of horticultural substrates: II. Predicting physical properties of media in containers. J. Amer. Soc. Hort. Sci. 114:53-56.

Milks, R.R., W.C. Fonteno, and R.A. Larson. 1989c. Hydrology of horticultural substrates: III. Predicting air and water content of limited-volume plug cells. J. Amer. Soc. Hort. Sci. 114:57-61.

Mualen, Y. 1976. A new model for predicting the hydraulic conductivity of unsaturated porous media. Water Resour. Res. 12:513-522.

Nobel, P.S. 1994. Root-soil responses to water pulses in dry environments, p. 285-304. In: M.M. Caldwell and R.W. Pearcy (eds.). Exploitation of environmental heterogeneity by plants. Ecophysiological processes above and belowground. Academic Press. San Diego, Calif.

Ordovás, J., E. Carmona, M.T. Moreno, and M.C. Ortega. 1996. Characteristic of internal porosity of cork container media. HortScience 31 : $1177-1179$.

Ordovás, J., E. Carmona, M.C. Ortega, and M.T. Aguado. 1997. Características físicas de sustratos de corcho y turba en macetas tras 2,5 meses de cultivo. Actas de Horticultura 18: 464-467.

Orländer, G. and K. Due. 1985. Location of hydraulic resistance in the soil-plant pathway in seedling of Pinus sylvestris L. grown in peat. Can J. For. Res. 16:115-123.

Orozco, R. 1995. Propiedades físicas e hidrológicas de perlitas utilizadas para cultivos sin suelo. Su implicación con las relaciones sustrato-aguaplanta y con el riego de cultivos hortícolas. 
PhD Thesis, Univ. de Lleida.

Orozco, R. and O. Marfà. 1995. Granulometric alteration, air-entry potential and hydraulic conductivity in perlites used in soilless cultures. Actas Hort. 408:147-161.

Otten, W. 1994. Dynamics of water and nutrients for potted plants induced by flooded bench fertigation: experiments and simulation. $\mathrm{PhD}$ Thesis, Agricultural Univ., Wageningen, The Netherlands.

Passioura, J.B. 1988. Water transport in and to roots. Ann. Rev. Plant Physiol. Plant Mol. Biol. 39: 245-265.

Raviv, M., H. Nerson, S. Medina, R. Berdugo, Y.
Shamir, A. Krasnovsky, and Z. Benner. 1993. Moisture tension of the growing medium and irrigation control of container-grown plants. $6^{\text {th }}$ Intl. Conf. Irrig. Proc. Tel-Aviv. p.199-209.

Rivière, L.M., J.C. Foucard, and F. Lemaire. 1990. Irrigation of container crops according to the substrate. Scientia Hort. 43:339-349.

Van Genuchten, R. 1978. Calculating the unsaturated hydraulic conductivity with a new closed-form analytical model. Res. Rpt. 78-WR-08, Water Resources Progr., Dept. of Civil Eng., Princeton Univ., Princeton, N.J.

Van Genuchten, M.Th. 1980. A closed-form equation for predicting the hydraulic conductivity of unsatured soils. Soil Sci. Soc. Amer. J. 44: 892-898.

Van Genuchten, M.Th. and D.R. Nielsen. 1985. On describing and predicting the hydraulic properties of unsaturated soils. E.G.S.; Ann. Geophysicae 3:615-628.

Wallach, R., F.F. Da Silva, and Y. Chen. 1992a Hydraulic characteristics of tuff (scoria) used as a container medium. J. Amer. Soc. Hort. Sci. 117:415-421.

Wallach, R., F.F. Da Silva, Y. Chen. 1992b. Unsaturated hydraulic characteristics of composted agricultural wastes tuff, and their mixtures. Soil Sci. 153:424-441. 